\title{
A new intermediate-depth ice-core drilling system
}

\author{
Simon G. SHELDON, Trevor J. POPP, Steffen B. HANSEN, Thomas M. HEDEGAARD, \\ Carsten MORTENSEN
}

Centre for Ice and Climate, Niels Bohr Institute, University of Copenhagen, Denmark

E-mail: sheldon@nbi.ku.dk

\begin{abstract}
Several recent projects associated with the IPICS (International Partnerships in Ice Core Sciences) $2 k$ array have demanded the recovery of ice core to depths in excess of several hundred metres (e.g. Flade Isblink, Greenland (2006), Aurora Basin, Antarctica (2008/09), NEEM, Greenland (2011), Aurora Basin North (2013/14) and Renland ice cap, Greenland (2015)). These projects require that the overall system weight is low, that the ability to set up and operate are within the limitations of a small-camp environment and that the overall logistical and transportation costs are kept to a minimum. Using these criteria, a new drilling system capable of drilling $>400 \mathrm{~m}$ depth was seen as a useful future development. Here we report on a new intermediate-depth drilling system designed to recover highquality $98 \mathrm{~mm}$ diameter ice cores from close to surface down to depths of $1000 \mathrm{~m}$ by two or more operators in a small deep-field camp environment. The total weight of the system on the snow surface is $\sim 490 \mathrm{~kg}$, of which the intermediate-depth winch is the single heaviest component at $305 \mathrm{~kg}$ with $1000 \mathrm{~m}$ of cable.
\end{abstract}

KEYWORDS: ice core, ice coring, ice engineering

\section{INTRODUCTION}

In 2006 a drilling expedition was mounted to recover ice core from Flade Isblink $\left(81.3^{\circ} \mathrm{N}, 15.7^{\circ} \mathrm{W}\right)$, northeast Greenland, a separate independent ice cap of the main Greenlandic ice sheet. The primary goal was to recover a continuous goodquality ice core with $98 \mathrm{~mm}$ diameter to bedrock ( 540 m depth), within the strictures of having a very low budget, set in a deep-field small-camp environment, using drilling equipment not designed for such an undertaking, and using a newly developed yet unproven drill liquid, ESTISOL ${ }^{\mathrm{TM}} 240$. The drilling system set-up was the Danish shallow winch and tilting tower, modified to contain $730 \mathrm{~m}$ of cable, with the Danish Hans Tausen (HT) drill. Until this expedition the deepest drilling achieved by this system was $344 \mathrm{~m}$ at Hans Tausen ice cap in 1995 (Johnsen and others, 2007).

During the expedition, many challenges and difficulties were encountered relating to adverse weather conditions at the site causing insufficient operation time, compounded by limitations found in the performance of the winch and tilting tower system. As the drilling operation approached drill depths close to $400 \mathrm{~m}$, the ascent speeds became slower and slower, which cumulatively increased the trip time. At these depths the motor used in the winch was being driven on a regular basis to $>60 \%$ over its maximum continuous rating (CMR-S1). These factors were finally responsible for a shortened season where $423 \mathrm{~m}$ of ice core was recovered.

After this season it was concluded that we were approaching the practical depth limits using the shallow winch in its present configuration. The absolute maximum achievable depth using this motor, even at these very high currents, was calculated at $590 \mathrm{~m}$. Below this depth the cable tension from the weight of the drill, ice core, ice chips and the cable downhole would exceed the ability of the winch system to lift the drill out of the borehole. There would be very limited tension available to break the ice core. Modifications required would involve

1. New stronger winch-drum side plates
2. New winch-motor gearbox combination capable of either

a. higher torque (while using the same gearbox),

b. higher rotation speed (with a gearbox with a higher step-down ratio)

3. A much more powerful winch controller with built-in descent control

4. An improved balanced tilting tower.

Of these the most challenging modification would be to improve the winch motor and gearbox to give sufficient torque (to break the ice core) and speed (to lift the drill back to the surface), all within the very tight confines inside the winch drum.

To implement these requirements would involve a complete redesign of the whole winch, tilting tower, support base and electrical control system. It should be noted that the shallow winch is very well suited to recovering ice cores down to a few hundred metres in open-field environments and has successfully fulfilled this role on many occasions in the past 40 years. It should also be noted that this useful role was seen as a drilling requirement for future projects. Therefore, for a future ice-core drilling operation involving depths greater than a few hundred metres, a completely new purpose-built intermediate-depth drilling system was deemed the best solution.

\section{MAIN DESIGN REQUIREMENTS}

The main design criteria of this new system were soon increased and expanded upon. Below is a list of some of these requirements:

Produce high-quality $98 \mathrm{~mm}$ diameter ice core

Designed to accommodate the Danish HT drill, the Danish borehole reamer selection, 


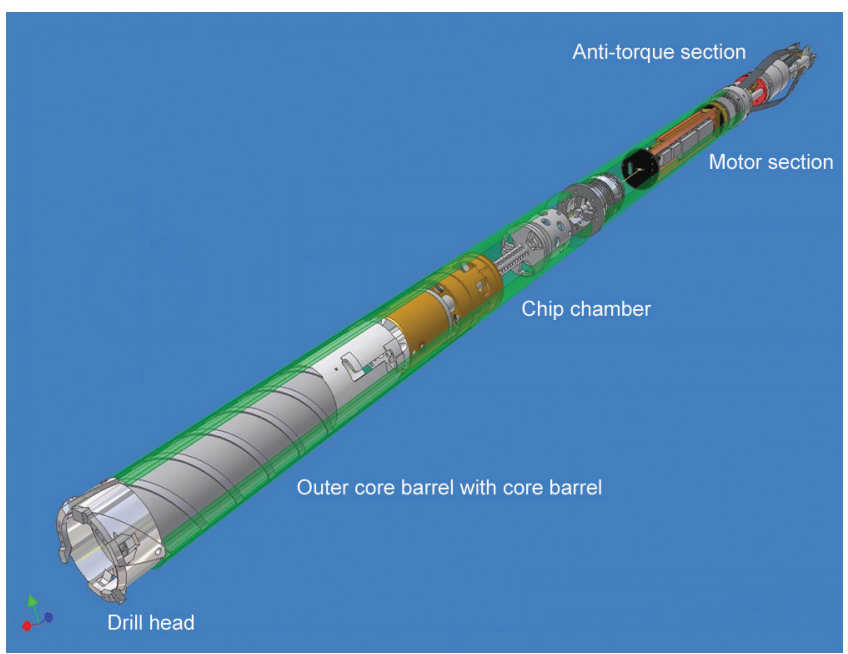

Fig. 1. HT drill: total weight $90 \mathrm{~kg}$ (empty).

the planned Danish HT 2.1 drill,

the Danish shallow drill

Operate from surface to depths in excess of $600 \mathrm{~m}$; a nominal $1000 \mathrm{~m}$ was an approximate aim

Operate with fast run times: drill ascents and descents of $\sim 1 \mathrm{~m} \mathrm{~s}^{-1}$

Low overall system weight: $<1000 \mathrm{~kg}$

Ability to set up and pack down quickly - within a few days

Operate within the limitations of a small-camp environment

Easy for two persons to operate

Overall logistical and transportation costs are kept to a minimum

Not excessively expensive to build

Reliable and easy to field-repair

Ability to be set up directly on the snow surface or be mounted on a Nansen sled and then moved

Ability to be transported

by Twin Otter,

by Basler Turbo 67,

by Hercules LC-130,

by normal international air freight

Where possible, use shared cross-platform components.

\section{MAIN DESIGN COMPONENTS AND FEATURES}

Having reviewed previous and existing designs, it was decided that the new system should be based on several aspects of the Danish deep drilling system, used successfully at the NorthGRIP (North Greenland Ice Core Project) and NEEM (North Greenland Eemian Ice Drilling) sites, and on some aspects of the Danish shallow drilling system, used successfully at Hans Tausen ice cap, Greenland; NorthGRIP; EPICA-DML (Dronning Maud Land), Antarctica; NEEM; Renland ice cap, Greenland, etc. Specifically, the winch and tilting tower would be set up separately several metres apart, coupled by beams, a similar concept to that used by

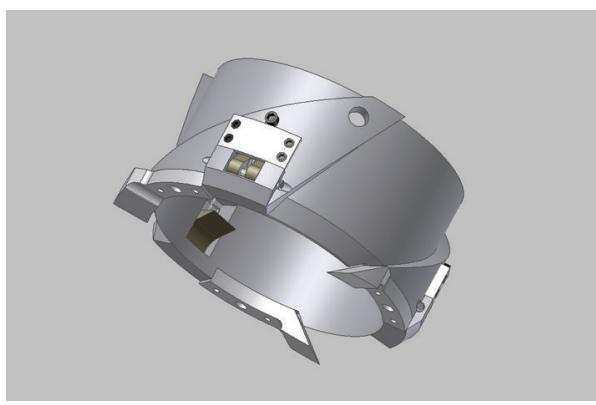

Fig. 2. HT drill head.

the Danish deep drilling system. The design of the tilting tower and support base, the type of cable and termination system, the anti-torque, the motor section and the overall electrical control system would be similar to the Danish shallow drilling system. By following these principles many previously tried and tested components could be easily and quickly produced, while making specific improvements to the performance and capabilities of the hoisting system and keeping the overall system weight low.

The major components are:

Ice-core drill, including a new anti-torque section, a new motor section and the HT drill in 'dry' and 'wet' modes.

New drill tilting tower and base support.

New intermediate winch with $1000 \mathrm{~m}$ of cable.

New drill and winch controller.

\section{Ice-core drill}

Since 1995 Denmark has been using a very successful icecore drill, the $5 \mathrm{~m}$ long HT $98 \mathrm{~mm}$ diameter ice-core drill (Johnsen and others, 2007; Fig. 1). This design has been either copied directly or used as a design concept by many ice-core drilling groups throughout the world. The design concept has been scaled up to 10-12.5 $\mathrm{m}$ for several deep ice-core drills (e.g. NorthGRIP, EPICA Dome C and NEEM drills). It has operated successfully at depths in excess of $3000 \mathrm{~m}$. The HT drill has two modes of operation: (1) dry mode, used from the surface down to $\sim 100 \mathrm{~m}$, and (2) wet mode, used from depths below $\sim 100 \mathrm{~m}$.

\section{Brief description of ice-core drill}

The HT drill has a very precisely designed and made drill head (Fig. 2) attached at its lowest point. It is directly connected to the core barrel and consists of three ice cutters, which when rotated cut a cylindrical groove into the ice, channelling the excess cuttings up out of the way of the drill head while leaving an intact ice core within the central free space. As the drilling progresses, this ice core slowly fills the core barrel above the drill head with a maximum length of $\sim 1.60 \mathrm{~m}$ of ice core. When the core barrel is full the drillhead rotation is stopped and the entire drill is then hoisted upwards. During this hoisting process, core dogs mounted in the drill head engage and cleave the ice core, allowing the drill to bring the core to the surface. There are slots for mounting three core dogs, though normally we use only two, which we have found has given better performance.

The HT core barrel (Fig. 3) is mounted inside the lower section of the HT drill within the outer core barrel section. During the drilling process, the drill head and core barrel are 


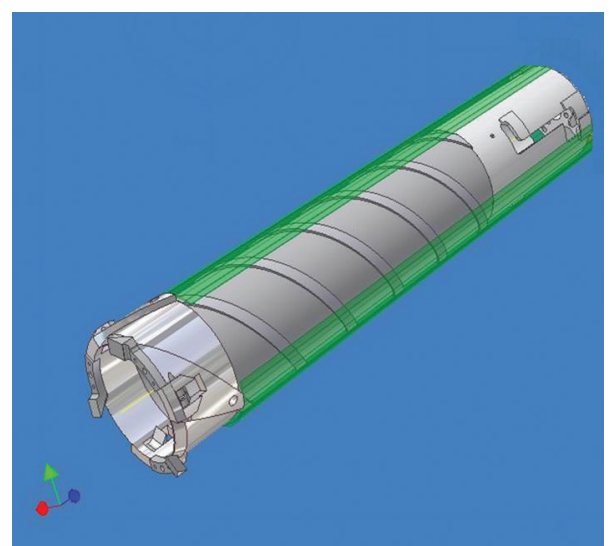

Fig. 3. HT drill head attached to the core barrel.

rotated while the outer core barrel is kept from rotating. The ice cuttings produced by the drill head are channelled up the drill by the action of rotating nylon spirals attached to the core barrel working in conjunction with vertical grooves on the inside of the outer core barrel. The chips are channelled up to the top of the core barrel where they enter and are temporarily stored in the chip chamber.

The chip chamber and hollow shaft (Fig. 4) has four major components. The chip chamber barrel is welded directly to the outer core barrel and is bolted to the top valve assembly. The chip chamber acts as a temporary container for the ice cuttings during the drilling process. After drilling has finished, the drill is hoisted to the surface and the ice cuttings, or 'chips', are removed from the chamber.

At the centre of the chip chamber is a hollow shaft with an Archimedes-type pump to help chip transport and drillliquid circulation. The hollow shaft connects the core barrel to the motor and thus rotates the drill head. At the top of the chip chamber is the top valve assembly which connects to the motor section.

The rotation of the HT drill's pump/booster, core barrel and drill head is powered by a Parvalux PM50 $160 \mathrm{~V}$ d.c. motor via a $1: 60$ reduction gearbox assembly set within a pressure-resistant container. The motor section can deliver $60 \mathrm{Nm}$ of torque while rotating the drill head at $60-80 \mathrm{rpm}$ at depth pressures in excess of $30 \mathrm{MPa}(300 \mathrm{~atm})$. The electrical power to the motor comes via three inner conductors and the outer armour of the cable used to hoist the drill up and down the borehole.

For the intermediate-depth drilling system a new version of our 'shallow' anti-torque section (Fig. 5) was manufactured. The anti-torque section is used to prevent the main drill body freely rotating in the borehole during ice-core drilling. This consists of three adjustable skates, or blades, set up to press firmly against the borehole wall so that they allow free and easy vertical motion while inhibiting rotation. Within the anti-torque the winch cable is terminated inside the $9.5 \mathrm{~kg}$ 'hammer' assembly. The cable can rotate freely in respect of the hammer assembly, but is constrained both vertically and horizontally. The hammer assembly has $\sim 10-20 \mathrm{~cm}$ of free vertical movement along support rails to allow an impact shock to break the ice core. After the drilling is completed, this set-up allows the hammer assembly to be lowered by simply slackening the cable, then by quickly raising the cable the hammer is accelerated into the top of the anti-torque to give an impulse shock to the drill to help break the ice core.

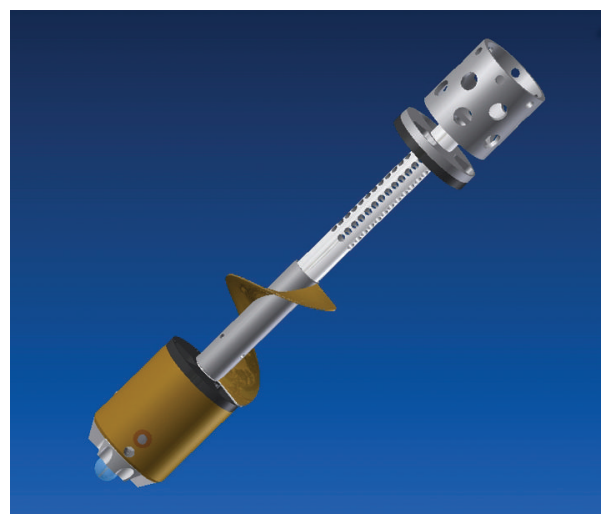

Fig. 4. Hollow shaft within chip chamber with spiral booster.

The cable is fixed inside the hammer assembly by a proprietary Danish termination system enabling the cable to be tensioned in excess of $12000 \mathrm{~N}$. At the cable termination the four inner electrical conductor wires are connected to a new slip-ring assembly (LTN ServoTechnik GmbH, threeway, $6 \mathrm{~A}, 500 \mathrm{~V}$, part No. 4938347). Three of these conductors provide electrical power to the drill motor, and the fourth is used to detect whether the anti-torque is rotating freely during drilling. At the very top of the antitorque section is an emergency steel loop. This is placed so that if the normal hoisting cable breaks close to the drill (e.g. at the termination point), a hook can be lowered down the borehole via another cable, which is attached to the loop, and the drill can be lifted back out of the hole.

\section{Tilting tower and support base}

A tilting tower system (Fig. 6) similar to the Danish shallow and deep drilling systems was considered the best way to handle the drill for drilling the ice core downhole, traversing up and down the borehole, and for extracting the recovered ice core on the surface. The tilting tower consists of a $3 \mathrm{~m}$ long, $0.25 \mathrm{~m}$ diameter aluminium tube with holding receptacles mounted on the upper side (when horizontal) for supporting the drill when extracting the core, and for mounting, cleaning and servicing purposes. This tube pivots $90^{\circ}$ from the horizontal to vertical about the supporting base, which can be mounted either directly on the snow

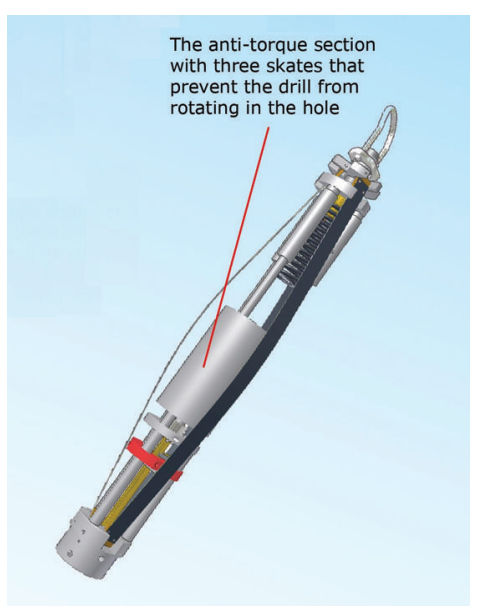

Fig. 5. Anti-torque used by the Danish HT and shallow drills. 


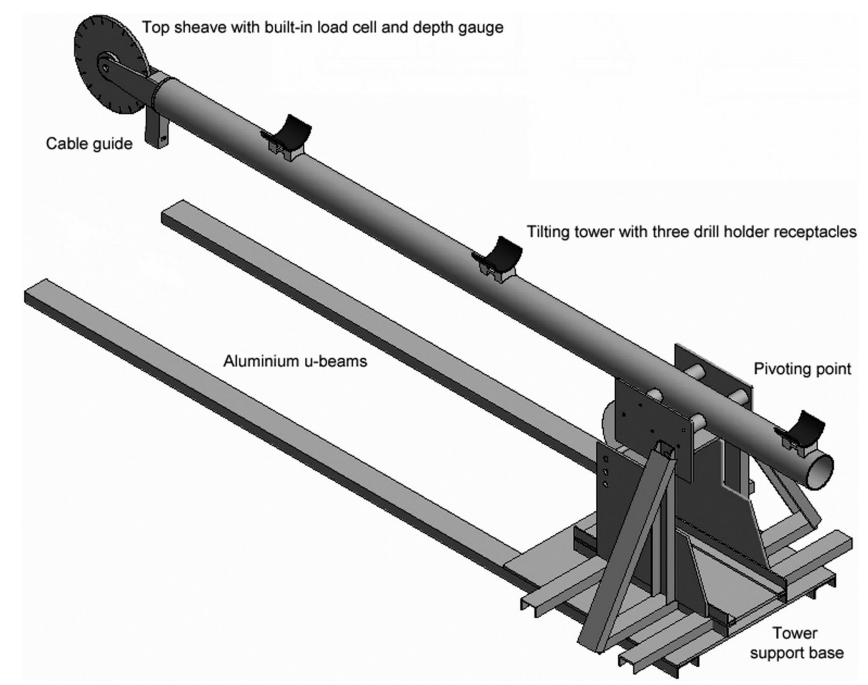

Fig. 6. Tilting tower, base support and beams in 'horizontal' mode. The tilting tower and support base require a dedicated space of $3.60 \mathrm{~m}$ (length) $\times 0.80 \mathrm{~m}$ (width) $\times 3.60 \mathrm{~m}$ (height), preferably within a shaded cold enclosure. The whole system weighs $<80 \mathrm{~kg}$.

surface or on a Nansen sled. The pivoting point is 0.80-1.00 $\mathrm{m}$ above the snow surface, allowing comfortable access to the drill when in the horizontal surface mode. When the tower is tilted $90^{\circ}$ in the vertical position, the tower rests firmly on the main base support plate to allow a strong and even distribution of vertical forces when, for instance, the drill is ascending the borehole, or when an icecore break is in progress downhole where force in excess of $4 \mathrm{kN}$ can occur.

Mounted on the upper section of the tower when vertical is a freely rotating grooved flywheel, or top sheave. The groove is specifically designed to guide the cable used to hoist the drill up and down the borehole. A cable guide is also mounted onto the tower to help facilitate stable cable movements. The grooved section of the top sheave is machined to provide a $1.00 \mathrm{~m}$ cable circumference. Ten submerged magnets mounted within the top sheave induce a depth counter sensor mounted on the tower for measuring the drill depth to $0.1 \mathrm{~m}$ resolution and hoisting speeds down to $1 \mathrm{~mm} \mathrm{~s}^{-1}$. At the centre of the sheave the axle has a built-in load cell to measure the vertical forces acting on the top sheave and, hence, to display the cable tension. The displayed cable tension is up to $1 \mathrm{~N}$ precision, a useful parameter for the drill operator to determine the 'weight-ondrill bit' at deeper drill depths and up to $>10 \mathrm{kN}$, useful during recovery and hoisting of the drill.

The tilting tower is designed to allow the $5 \mathrm{~m}$ long 4-inch $(98 \mathrm{~mm}) \mathrm{HT}$ drill, the $4 \mathrm{~m}$ long Danish 3-inch $(76 \mathrm{~mm})$ shallow drill, and the future planned $6 \mathrm{~m}$ long 4-inch HT 2.1 drill to be positioned so that when tilting the drill the tower is in balance with minimal user input. Mounted on the base support is a second grooved flywheel, the base sheave, which helps guide the cable from the top sheave to the winch while minimizing the change in cable length during the tilting of the tower. The base sheave freely rotates about its axis while able to slide sideways $\pm 0.18 \mathrm{~m}$ about the centre of the base. This sliding feature halves the fleet angle by doubling the free movement length of cable from the top sheave to the winch drum from $3 \mathrm{~m}$ to $6 \mathrm{~m}$, halving the inward perpendicular cable force at the winch drum. This feature greatly reduces the problems with guiding the cable

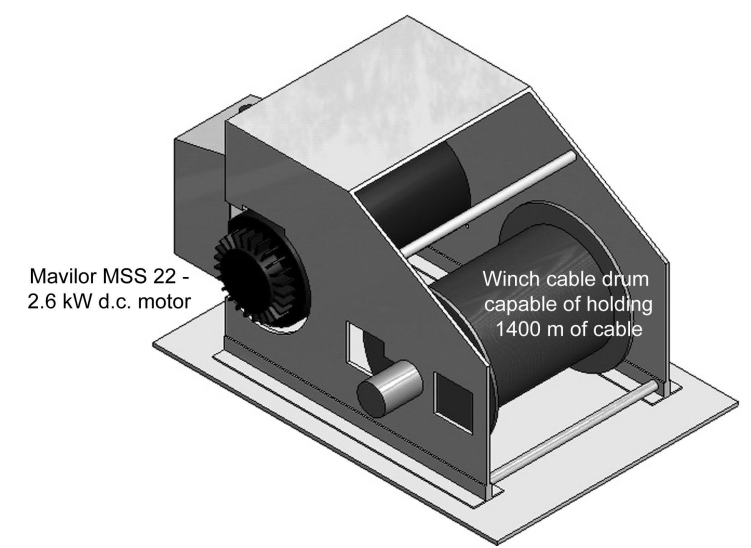

Fig. 7. Intermediate-depth winch.

onto the winch drum and almost eliminates the requirement of a winch-spooling guide system (see 'Future system development' below).

The support base is mounted onto two parallel $3 \mathrm{~m}$ long $0.15 \mathrm{~m} \times 0.04 \mathrm{~m}$ aluminium u-profile beams which are designed to slide and fit inside the dismantled tower tube during transportation. The primary purpose of these beams is to prevent the support base from being pulled towards the winch when the cable is under high tension, such as during the hoisting process of the drill or during an ice-core break. These beams also help prevent the effects of the cantilever forces developed by the cable tension due to the height differences of the bottom sheave groove and the point where the cable spools onto the cable drum (Fig. 7).

\section{Intermediate-depth winch}

The intermediate-depth winch is a development based on a highly modified AusLog 2000 winch. The AusLog 2000 winch is a standard off-the-shelf purchase, constructed mainly in aluminium for a strong lightweight structure; the winch is a rugged design with many useful attributes. The purchase of this winch was seen as a good opportunity to save on expensive engineering and machining time.

The winch consists of two heavy-duty side plates, fixed in a rigid construction by a base plate, internal rods and a back/top plate, all made in anodized aluminium. An aluminium cable drum has a LeBus grooved drum mounted on to help cable spooling, and can hold $>1400 \mathrm{~m}$ of $5.7 \mathrm{~mm}$ diameter cable. This drum assembly is supported by a central axle on bearings held by the two heavy-duty side plates. The drum has a disc-brake assembly mounted for emergencies and fixing the drum during transportation. The cable drum is rotated by a chain drive connected to a d.c. motor via a gearbox-and-clutch assembly. The clutch can release or engage the cable drum from the motor drive system if required.

The d.c. motor used is a $2.6 \mathrm{~kW}$ Mavilor MSS-22 with internal $24 \mathrm{~V}$ brake and tachometer providing $8.2 \mathrm{Nm}$ of continuous maximum rated torque (CMR-S1) and a maximum continuous rotation speed of $3000 \mathrm{rpm}$. The gearbox used is a SITI MHL 25/2 11.92 Pam 28/250 B3 100/112 B5 which provides a gearing reduction ratio of $1: 11.92$. The chain drive provides an additional reduction ratio of $1: 4.4$, giving a total gearing reduction ratio of $1: 52.4$. From this gearing, $427 \mathrm{Nm}$ of torque is available on the cable drum axle when the d.c. motor and gearing system is used within its normal continuous working limits. 
Table 1. Cable tension $(\mathrm{N})$ calculated for the required drilling depths, to check that the winch system could provide adequate torque to hoist the drill

Cable tension (combined weight Tension from winch CMR-S1* of drill and cable) $(\mathrm{STD}-\mathrm{S} 2-30 \mathrm{~min})^{+}$
Excess tension CMR-S1*

$(\mathrm{STD}-\mathrm{S} 2-30 \mathrm{~min})^{+}$

\begin{tabular}{lcl}
\hline Operating close to surface & 980 & $2350(3080)$ \\
Operating at $1000 \mathrm{~m}$ depth & 2170 & $4750(6240)$ \\
\hline
\end{tabular}

*IEC 60034-1 continuous maximum rating.

${ }^{+}$IEC 60034-1 short time duty (S2 - $30 \mathrm{~min}$ ). More relevant for hoisting operations than the continuous maximum rating

Table 2. Ascent speed $\left(\mathrm{m} \mathrm{s}^{-1}\right)$ calculated for different scenarios, to determine whether the winch system is capable of hoisting the drill at speeds close to $1 \mathrm{~m} \mathrm{~s}^{-1}$

\begin{tabular}{lcc}
\hline & $\begin{array}{c}\text { Drill ascent speed } \\
\text { CMR-S1* }\end{array}$ & $\begin{array}{c}\text { Motor at } 4500 \mathrm{rpm}^{\prime} \\
\text { STD-S2 }-30 \mathrm{~min}^{+}\end{array}$ \\
\hline $\begin{array}{l}\text { Operating at depths close } \\
\text { to surface } \\
\text { Operating at depths down } \\
\text { to } 840 \mathrm{~m} \\
\text { Operating at depths down } \\
\text { to } 1000 \mathrm{~m}\end{array}$ & 0.68 & 1.64 \\
\end{tabular}

*IEC 60034-1 continuous maximum rating.

${ }^{+}$IEC 60034-1 short time duty (S2 - 30 min) More relevant for hoisting operations than the continuous maximum rating.

Drilling from the surface down to $1000 \mathrm{~m}$ depth, the new winch theoretically should easily be capable of holding and lifting the combined weight of drill, ice core and cable. As added confidence, when using the winch in normal short non-continuous modes of operations, such as defined by IEC 60034-1 short time duty (S2 - 30 min), these motors can provide $>31 \%$ higher torque and $50 \%$ higher rotation speeds compared to continuous maximum ratings (CMR-S1) (Table 1).

Furthermore, when used in cold environments like those normally found in Greenland or Antarctica, the thermal loading on the wires is lower, so even greater currents can be used for short time periods. This allows even higher torque values than those from the STD-S2 - $30 \mathrm{~min}$. From our past experience with these types of motor used in these conditions we have regularly exceeded the CMR by $60 \%$. This has worked very well while the motor is rotating and thus quickly distributing the thermal load between the motor windings. If the motor is static the wiring can be quickly burnt out, so these extra-high currents are not advisable unless the motor is rotating.

Theoretically, the winch system can hoist the drill at speeds in excess of $1 \mathrm{~m} \mathrm{~s}^{-1}$ from $840 \mathrm{~m}$ depth to the surface. At greater depths the drill ascent speed is only slightly lower. The Mavilor MSS-22 motor, capable of rotation speeds from 0 up to $4500 \mathrm{rpm}$ with almost constant torque, provides a very flexible speed range for both low drilling speeds of $3-4.5 \mathrm{~mm} \mathrm{~s}^{-1}$ and high ascent speeds from 0.8 to $1.6 \mathrm{~m} \mathrm{~s}^{-1}$ (Table 2).

To cope with the cold environment, to which the winch will be subjected in normal working conditions, all bearings and lubricants were changed for low-temperature types, and a temperature-regulated $200 \mathrm{~W}$ heating system added to the SITI gearbox to help reduce viscous resistance of the gearbox oil during very cold conditions $\left(<-35^{\circ} \mathrm{C}\right)$. The main components of the new intermediate-depth drilling system can be seen in Table 3.

\section{Winch-and-drill controller}

To operate the intermediate-depth drilling system (Figs 8 and 9), a new electrical controller was designed (Fig. 10). The design concept is based around the Danish shallow winch-and-drill controller so the new controllers could directly interchange with the older controller. The new controllers are built within a rugged stainless-steel housing which is waterproof to IP $69 \mathrm{~K}$ standard, with an additional protective top cover plate for protecting the controls during transportation and shielding them from bright light conditions during operation.

The primary functions of the controller are to accurately position the drill within the borehole, power the drilling procedure, and retrieve the drill with core. To achieve these functions, the winch-and-drill controller contains several

Table 3. Summary of major components and features of the winch

\begin{tabular}{|c|c|c|c|c|c|}
\hline Winch drum & $\begin{array}{l}\text { Aluminium } \\
\text { construction }\end{array}$ & $\begin{array}{l}\text { LeBus internal cable } \\
\text { guide drum plates }\end{array}$ & $\begin{array}{l}\text { Capable of holding } \\
\text { up to } 1400 \mathrm{~m} \text { cable }\end{array}$ & Dual disc brake & \\
\hline Cable & $\begin{array}{l}\text { Manufacturer: } \\
\text { Rochester Corp. }\end{array}$ & $\begin{array}{c}\text { Stock type } 4-\mathrm{H}-220 \mathrm{k} \text { cable } \\
\text { - part No. A240218 }\end{array}$ & $\begin{array}{l}5.66 \mathrm{~mm} \text { diameter } \\
4 \text { inner conductors }\end{array}$ & $\begin{array}{l}\text { Breaking strength } \\
20.5 \mathrm{kN}\end{array}$ & $\begin{array}{c}\text { Danish termination, } \\
\max .7 .5 \mathrm{kN}\end{array}$ \\
\hline Slip-ring & $\begin{array}{c}\text { Manufacturer: } \\
\text { LTN ServoTechnik GmbH }\end{array}$ & Part No. 4938347 & 3 contacts, $6 \mathrm{~A}$ each & $500 \mathrm{~V}$ d.c. insulation & $\begin{array}{l}\text { Tested } 2500 \mathrm{~m} \text { depth } \\
\text { and to }-55^{\circ} \mathrm{C}\end{array}$ \\
\hline Winch drive & D.c. motor & With electromechanical brake & SITI MHL gearbox & Clutch system & Chain drive $1: 4.4$ \\
\hline $\begin{array}{l}\text { Dimensions } \\
\text { and weights }\end{array}$ & $\begin{array}{l}\text { Standard Euro pallet } \\
(1.2 \mathrm{~m} \times 0.80 \mathrm{~m} \times 0.90 \mathrm{~m})\end{array}$ & $\begin{array}{c}280 \mathrm{~kg} \\
\text { (with } 830 \mathrm{~m} \text { of cable) }\end{array}$ & $\begin{array}{c}302 \mathrm{~kg} \\
\text { (with } 1000 \mathrm{~m} \text { of cable) }\end{array}$ & $\begin{array}{c}355 \mathrm{~kg} \\
\text { (with } 1400 \mathrm{~m} \text { of cable) }\end{array}$ & \\
\hline
\end{tabular}




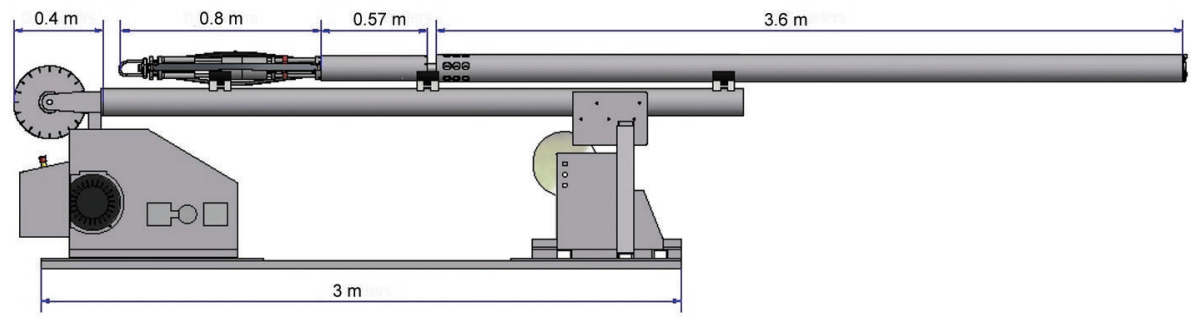

Fig. 8. Intermediate-depth drilling system side view.

distinct sets of electronics which are set up to minimize the complexity for the operator, while providing all the required control functions, display the relevant parameters and allow for a versatile safe set-up.

\section{OPERATOR INTERFACE}

The controller front panel is designed with clear and easyto-read displays, has large controls for outdoor use, particularly with polar gloves, and a clutter-free easy-tooperate layout. It is divided into three functional areas: (1) The winch motor control and display, (2) the drill motor control and display and (3) drill depth, load-cell display, emergency stop and internal temperature.

The winch motor control-and-display area of the control top panel contains a large easy-to-handle switch to turn the winch motor on/off and also sets the hoisting direction, either ascending or descending, in the borehole. The winch motor speed is set by a large easy-to-handle potentiometer knob close to the on/off switch. The winch motor current is displayed, indicating the stresses exerted by the winch motor, both in analog and digitally. This display is useful so the operator can judge whether the winch is functioning correctly. On the analog section of the motor current display, there are normal (indicated by green) and dangerously excessive (red) operating currents.

Similar to the winch control the drill motor control-anddisplay area of the control top panel contains a large easyto-handle switch to turn the drill motor on/off and also set the direction of rotation, either rotating the drill head forward or backwards. The drill motor speed is set by a large easy-to-handle potentiometer knob close to the on/off switch. The drill motor current is displayed, indicating the stresses exerted by the drill motor, both in analog and digitally. This display is useful to indicate whether the drilling is proceeding normally or when the core barrel and chip chamber is becoming full.

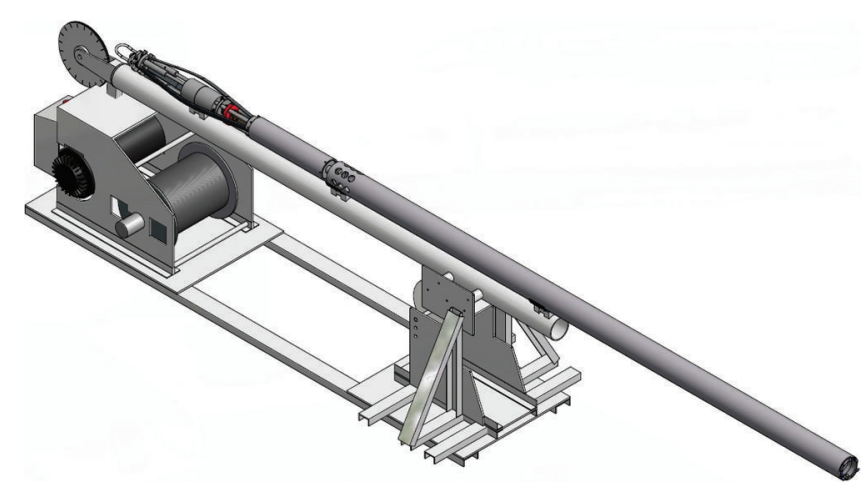

Fig. 9. Intermediate-depth drilling system.
The third functional area on the top control panel has a digital depth display for indicating the drill depth $(10 \mathrm{~cm}$ resolution) with a reset button, and a button to switch to hoisting speed. There is a mixed digital and analog display which indicates the drill and cable weight from the top sheave. On the analog section of the load cell display there are normal (indicated by green) and dangerously excessive (red) cable tensions. This display can be zeroed, or tared, to indicate the 'weight on drill bit' during the drilling procedure. This display also saves the maximum and minimum tensions useful for determining what force was required to break the ice core. Within this area of the control top panel there is also a display of the controller internal temperature and an emergency stop button.

\section{ELECTRICAL FUNCTIONS AND SPECIFICATIONS}

The electrical control system is powered by a single-phase $\sim 230 \pm 20 \mathrm{~V}$ a.c. at up to $16 \mathrm{~A}$. A single-phase $5 \mathrm{kVA}$ generator with voltage-regulated output is recommended for altitudes up to $1000 \mathrm{~m}$ a.s.I. All connecting electrical cables are silicon or PTFE types, rated to below $-55^{\circ} \mathrm{C}$ and for use in adverse industrial conditions.

The winch controllers on the top panel control a fully regulated motor driver, a Parker 514C 32A SSD, which drives and regulates a current through the Mavilor MSS 22 winch motor and switches the electromechanical motor brake on and off. The Parker 514C 32A SSD is a fully integrated bidirectional (bipolar) motor driver, configured for speed set operation using the motor armature voltage as feedback. Thus, the driver can accelerate or reduce the motor speed to the rotation speed setting. For instance, when the drill goes down the borehole, the descent speed is set by the operator and can be very quickly reduced to stop the descent, using the winch motor without using the mechanical brakes. The motor driver can deliver up to a maximum of $\pm 32 \mathrm{~A}$ at $180 \mathrm{~V}$,

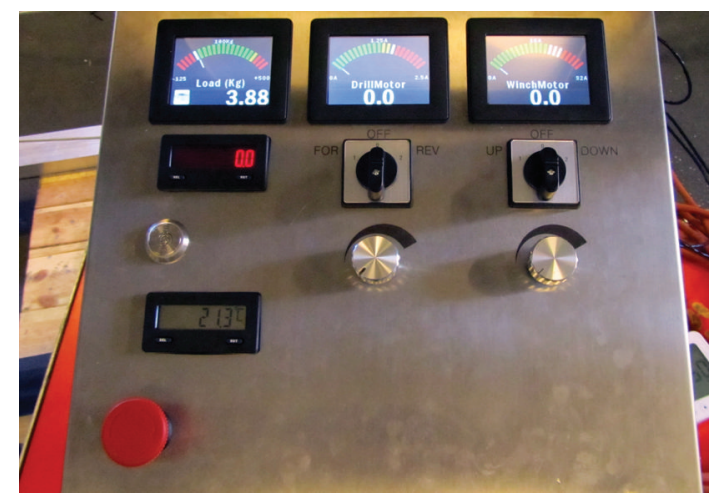

Fig. 10. Winch-and-drill controller. 
Table 4. Surface and shipping weights and dimensions

\begin{tabular}{|c|c|c|c|}
\hline & $\begin{array}{c}\text { Surface } \\
\text { weight } \\
\text { kg }\end{array}$ & & $\begin{array}{c}\text { Shipping } \\
\text { weight } \\
\text { kg }\end{array}$ \\
\hline Set-up on ice surface & & $\begin{array}{l}\text { Packed items (including } \\
\text { all spares, tools, boxes, } \\
\text { pallets and covers) }\end{array}$ & \\
\hline HT drill & 90 & Drill, reamer, spares & 345 \\
\hline Tilting tower and base & 80 & Tilting tower and base & 120 \\
\hline Winch & 280 & Winch and spares & 415 \\
\hline \multirow[t]{2}{*}{ Controller and cables } & 40 & Controllers and spares & 185 \\
\hline & & Tools & 70 \\
\hline \multirow[t]{2}{*}{ Total } & 490 & Total & $\begin{array}{r}1135 \\
\left(4.5 \mathrm{~m}^{3}\right)\end{array}$ \\
\hline & & \multicolumn{2}{|l|}{ Dimensions } \\
\hline Heaviest item (winch box) & 325 & \multicolumn{2}{|c|}{$\begin{array}{l}1.20 \mathrm{~m} \times 0.80 \mathrm{~m} \times 0.90 \mathrm{~m} \\
\quad(\text { standard Euro pallet })\end{array}$} \\
\hline Longest item (HT drill box) & 90 & \multicolumn{2}{|c|}{$3.80 \mathrm{~m} \times 0.25 \mathrm{~m} \times 0.25 \mathrm{~m}$} \\
\hline
\end{tabular}

which is $100 \%$ higher than the continuous maximum rating (CMR-S1) of the winch motor. The driver output current has been manually set so that it cannot deliver higher than $\pm 24 \mathrm{~A}$, or $50 \%$ higher than the winch motor's continuous rating.

The drill controllers on the top panel control a second fully regulated motor driver, a Parker 508 12A SSD, which drives and regulates a current through the Parvalux PM50 160 V d.c. drill motor via the hoisting cable. The Parker 508 $12 \mathrm{~A}$ SSD is a fully integrated unidirectional (unipolar) motor driver, configured for speed set operation using the motor armature voltage as feedback. Thus, the driver can accelerate the motor speed to the rotation speed setting, but requires mechanical resistance to slow and stop rotation. This works well with the drill, where there is always some resistance to rotation. The $230 \mathrm{~V}$ a.c. power supply for the drill motor driver is galvanically isolated from the mains power input using a 1:1 transformer. This is necessary due to the drill motor using the 'grounded' cable screen for power return which would otherwise unnecessarily 'trip' the protective residual current detectors (RCDs). The motor driver can deliver up to a maximum of $12 \mathrm{~A}$ at $180 \mathrm{~V}$ d.c. which is several times higher than the continuous rating of the drill motor. The driver output current has been manually set so that it cannot deliver higher than $2.5 \mathrm{~A}$, or $50 \%$ higher than the drill motor's CMR-S1.

The other electronics within the winch-and-drill controller include an amplifier/driver for the load cell, an internal temperature regulator, a depth counter, a multiple point emergency stop system and several layers of electrical and user safety features, including RCDs, over-current contact breakers (CBs), over-current fuses, over-voltage protector systems and full component 'grounding'. (Exposed external metal or conductive surfaces are connected to a common zero voltage reference point or 'ground'. The reference point for the whole camp is a single point on the power generator chassis. For safety purposes this common reference voltage acts as a 'ground'. For instance if currents greater than $30 \mathrm{~mA}$ are leaked from the 'live' or the 'neutral' of the mains to this 'ground', the RCD will cut the power to the affected circuit. 'Grounded' components are less likely

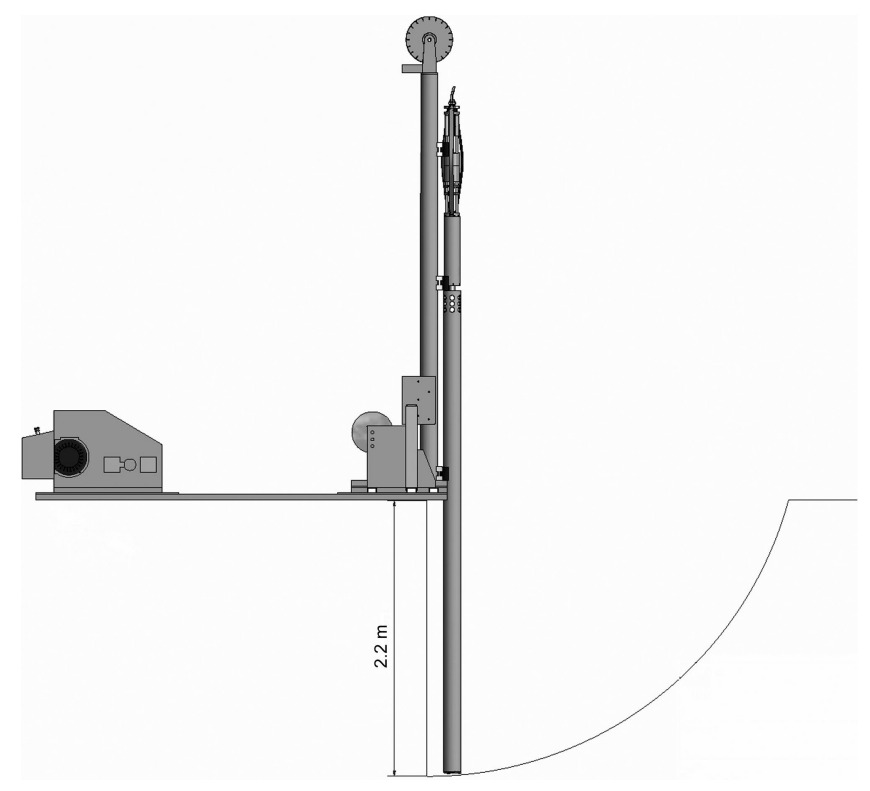

Fig. 11. The $2.2 \mathrm{~m}$ deep inclined trench.

to suffer from static build-up and discharge. This voltage reference is floating compared to the actual Earth ground underneath the ice shelf, to which users will not normally be exposed. When the drilling operation does approach the bedrock, the camp 'ground' can be referenced directly to the actual Earth ground via the drill and cable.)

\section{WINCH AND TOWER SYSTEM DIMENSIONS}

To use the intermediate-depth drilling system in a polar environment for 1, 2 or 3 months it is necessary to set it up in a suitable weather-resistant structure. The structure needs to conform to certain minimum dimensions, not only to allow the equipment to fit, but also so the drilling system can be operated and serviced in a comfortable usable way. These dimensions include space taken by the drilling system when tilted horizontally and vertically, space required for loading/unloading the core barrel, space for the controller and operator, space for servicing the drill components, and space for extracting, logging, temporarily storing, and packing the ice cores (Table 4; Figs 11-14).

\section{NEEM FIELD TESTS}

In May 2012 the new system was set up for field trials at NEEM, northwest Greenland $\left(77.45^{\circ} \mathrm{N}, 51.06^{\circ} \mathrm{W}\right)$. The winch, base support, tilting tower and a developmental electronic controller were unpacked, assembled and set up on a Nansen sledge (Fig. 15). The winch cable was initially unwound off the winch and then re-spooled back onto the winch with tension.

The Nansen sled was then towed and positioned into a large WeatherPORT tent shelter normally used as a storage garage (Fig. 16). A $2.2 \mathrm{~m}$ deep inclined trench was dug and the drill assembled in dry mode on the tilting tower (Fig. 11). The position of the HT drill was set so that the tilting tower was slightly out of balance without containing an ice core and had a roughly similar negative imbalance when containing an ice core. Assembly and preparation took 2 days by three operators. Drilling started on the third day. 


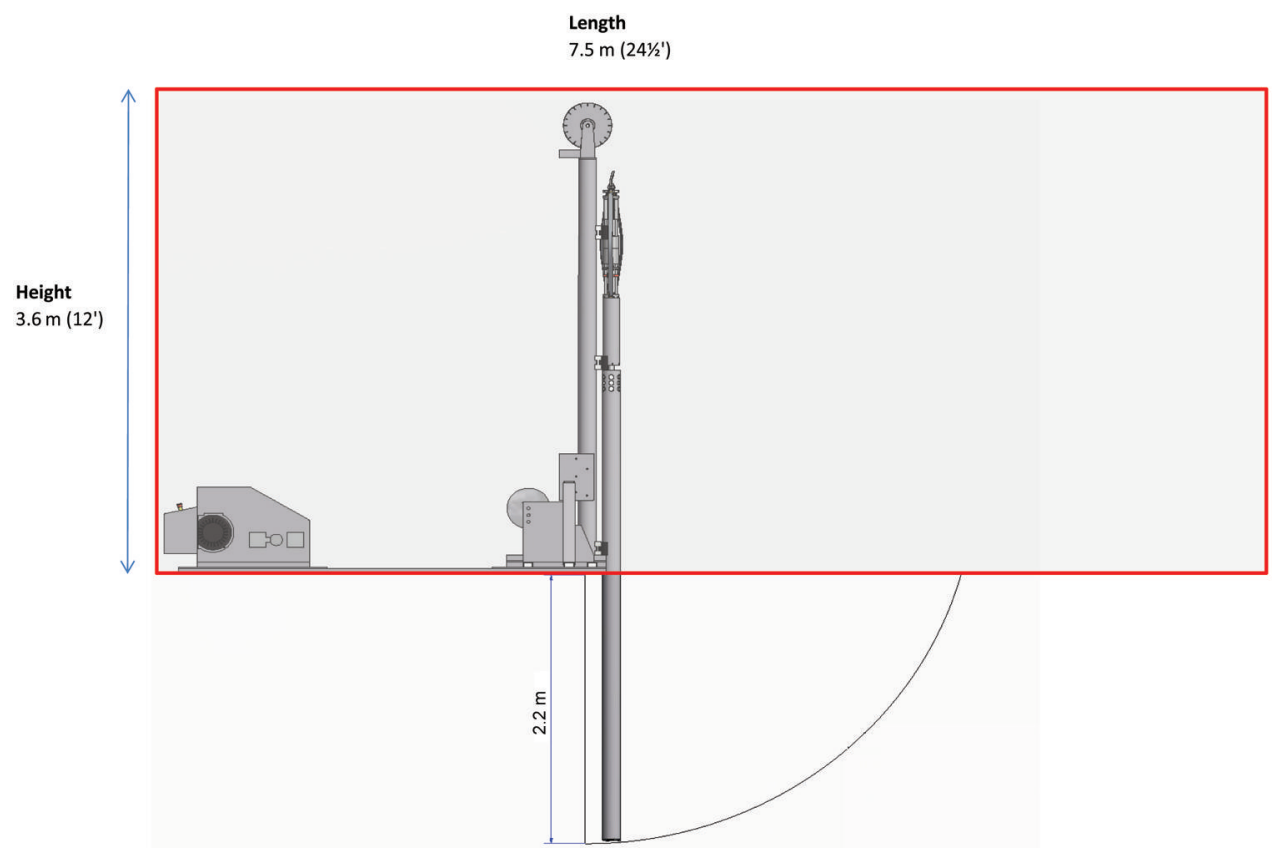

Fig. 12. Minimum working height of tilting tower and normal depth of inclined trench.

Initially, adjustments were made to the system to test maximum working limits. These adjustments were then set for normal safe working limits and the system adjusted for good usability. For instance, when equipment had been shipped from Copenhagen, all the electrical settings had been set to very low levels so they could be safely and slowly increased in the field. Adjustments included changing the shipped gearbox from a $1: 8.6$ reduction ratio to a newly purchased $1: 11.9$ ratio gearbox, so as to increase torque on the winch drum and thus increase the usable tension on the cable. Also, the drill was further repositioned on the tilting tower for improved balance. Several adjustments to the winch motor control were made, such as the motor current upper limits, motor acceleration/deceleration settings, and motor current stability settings. The winch brake on/off function was integrated into the winch on/off/direction switch to improve operator usability. The direction and calibration settings of the load cell were also adjusted.

After 8 days drilling both in dry and wet modes, the tests were concluded at $131 \mathrm{~m}$ depth (Fig. 17). Generally, the new drilling system produced excellent-quality ice core and functioned well within its designed criteria (Figs 18-22). The winch functioned well at accelerating/decelerating the drill, at holding the drill at any given depth, and at low to high speeds $\left(0.1-2.5 \mathrm{~m} \mathrm{~s}^{-1}\right.$ ) (Table 5). But instability was encountered at very low speeds $\left(0.5-10 \mathrm{~mm} \mathrm{~s}^{-1}\right.$, a necessary descent speed range during the drilling operation).

After the 2012 tests, the lessons learnt were applied. For instance, the design of the new drill-and-winch controllers was finalized and three were constructed, adjusted and

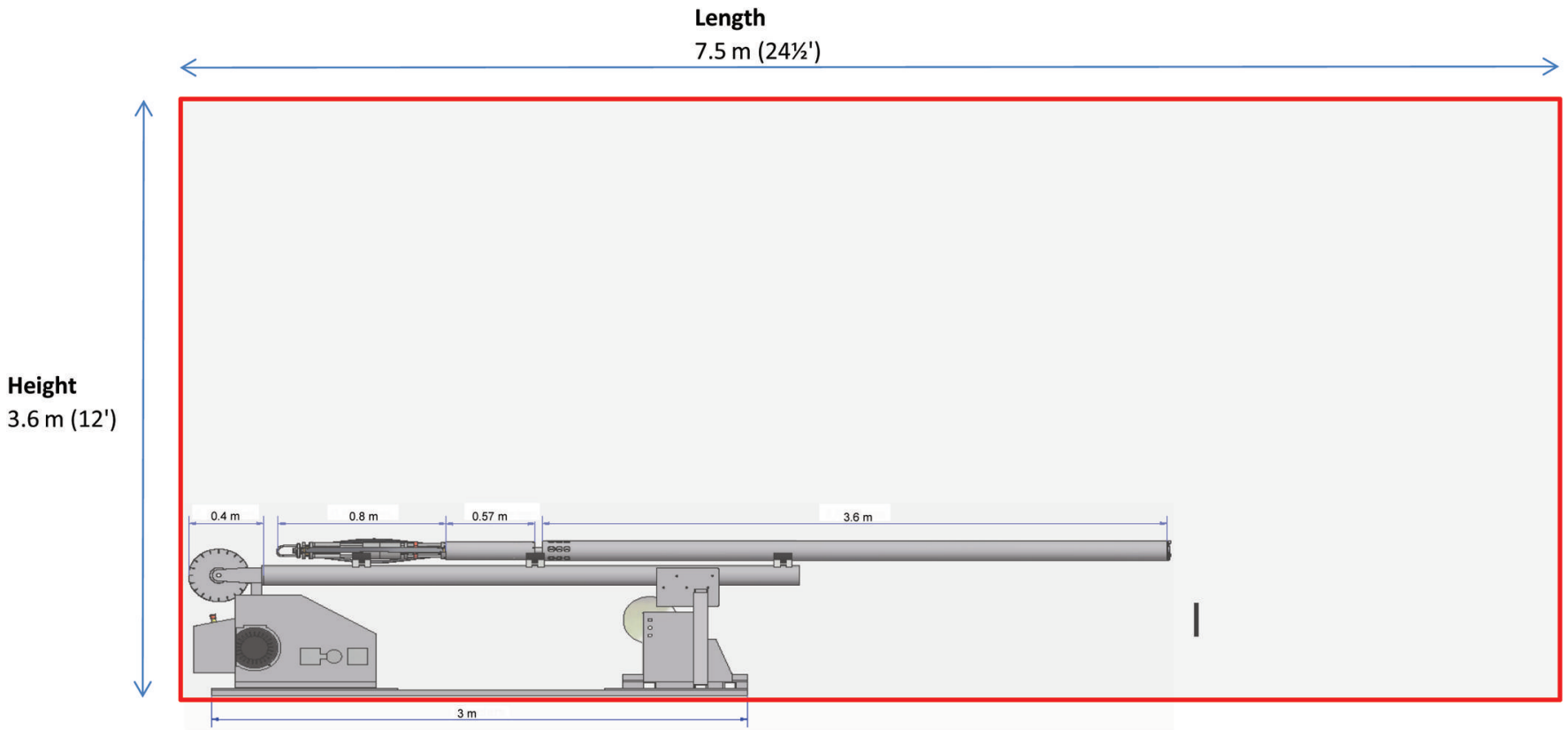

Fig. 13. Minimum working length of drill on tilting tower, including required space for loading and unloading the core barrel. 


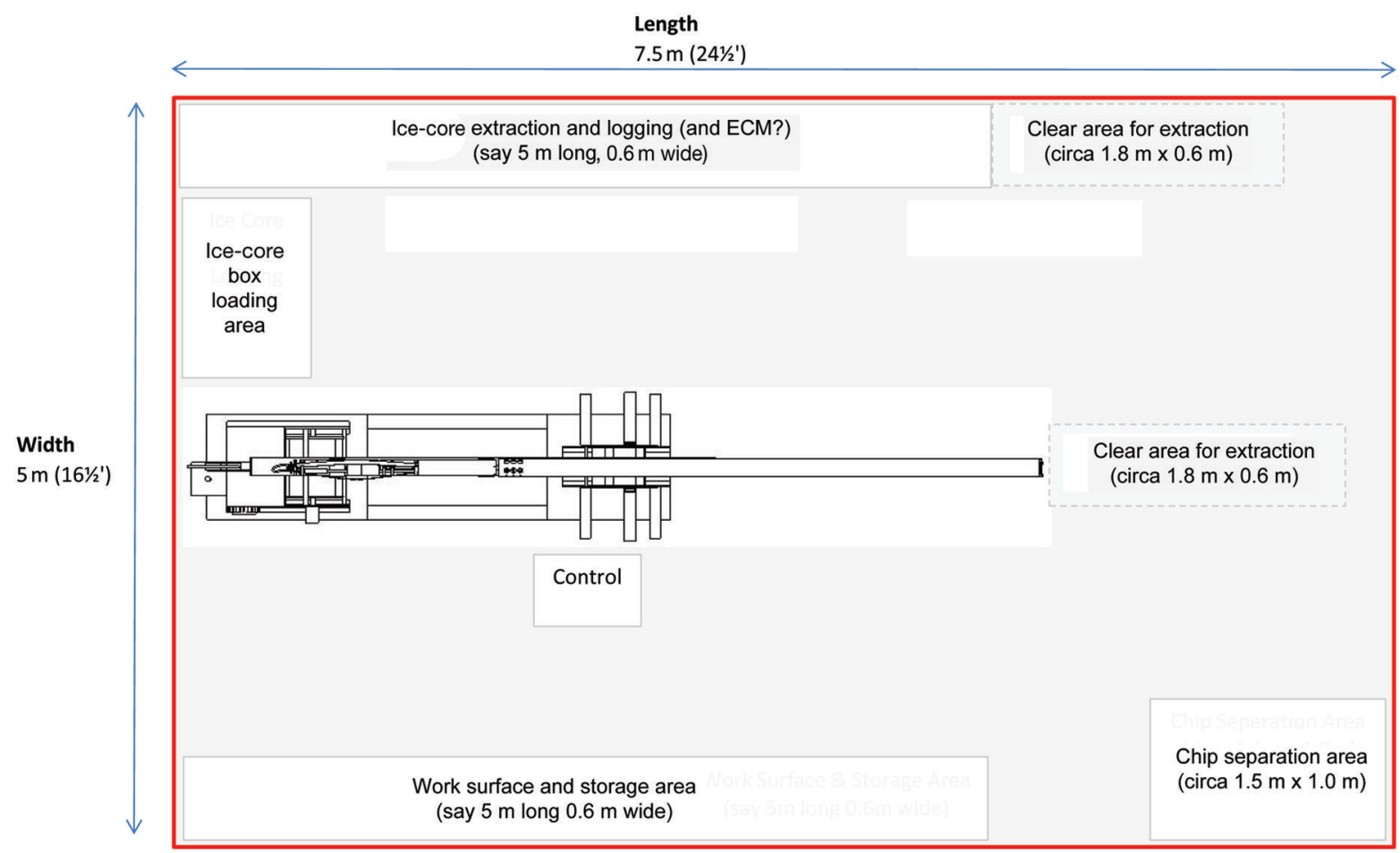

Fig. 14. A reasonable working environment for the system, with area dedicated for drill maintenance, for chip separation, for drill/winch control, for core barrel extraction, for ice-core extraction and core logging, and for operators to stand while extracting an ice core from a core barrel placed on the extraction table.

thoroughly tested in the laboratory and freezer; a new stronger winch top-and-rear plate was made to replace the two thin original plates; and a waterproof (IP69K) electrical junction box was added to the winch, with extra electrical and user safety features, such as multi-point emergency winch stop buttons, winch and drill electrical safety fuses, and the $33 \mathrm{mH}$ inline inductor to eliminate very low winchspeed instability. Many spare components were purchased specifically as spares for approaching field seasons.

The cable used at NEEM was replaced with $830 \mathrm{~m}$ of new cable wound onto the winch drum, with $\sim 2800 \mathrm{~N}$ tension applied to give a tight ready-to-use winch system and avoid cable tensioning in the field. The cable termination was fully tested electrically - rotating the drill and testing the antitorque slip warning alarm - and physically - the winch was powered with $131 \%$ over the winch motor CMR-S1rating, developing an excess of $4 \mathrm{kN}$ cable tension with $830 \mathrm{~m}$ on the drum. Starting with $1 \mathrm{~m}$ of slack cable, the winch developed an excess of $5 \mathrm{kN}$.

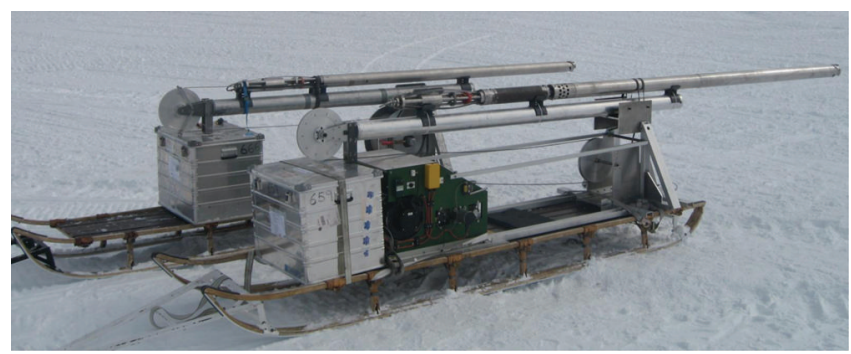

Fig. 15. Left to back: the Danish 3-inch shallow drill, shallow winch and tilting tower mounted on a Nansen sled. Right to front: the HT drill, intermediate winch and tilting tower mounted on a Nansen sled. NEEM 2012.

\section{AURORA BASIN NORTH PROJECT 2013/14}

In late December 2013 the intermediate-depth drilling system was set-up at Aurora Basin $\left(71^{\circ} 10.1^{\prime} \mathrm{S}, 111^{\circ} 23.8^{\prime} \mathrm{E}\right.$; $\sim 2700$ ma.s.l.; Fig. 23) within the East Antarctic high plateau, $\sim 525 \mathrm{~km}$ from the Australian coastal base, Casey Station. Upon arrival at the site, a $1.5 \mathrm{~m}$ deep trench was excavated using a snow blower and then covered by a

Table 5. Tested performance of the system and final safe user settings

Max tested Final setting

$\begin{array}{lcc}\text { Drill ascent speed in borehole }\left(\mathrm{m} \mathrm{s}^{-1}\right) & 2.5 & 1.5 \\ \text { Drill descent speed in borehole }\left(\mathrm{m} \mathrm{s}^{-1}\right) & 2.5 & 1.5 \\ \text { Max cable tension }(\mathrm{kN}) & 5 & 4\end{array}$

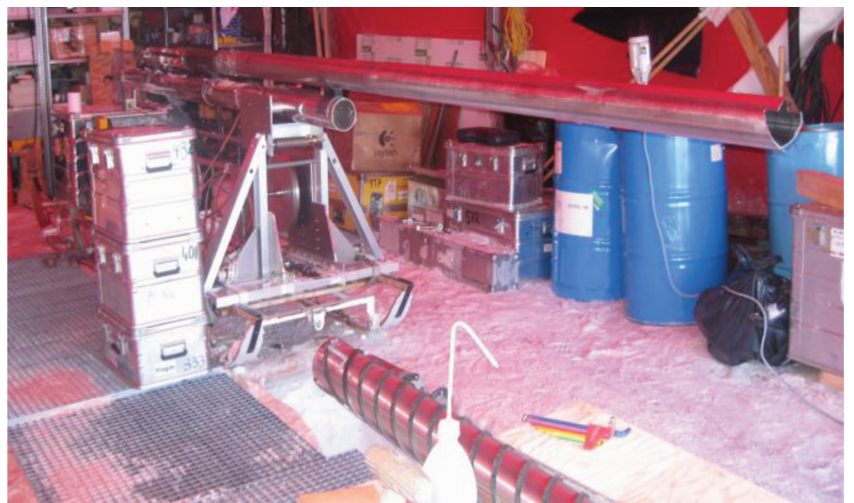

Fig. 16. System set-up at NEEM. 


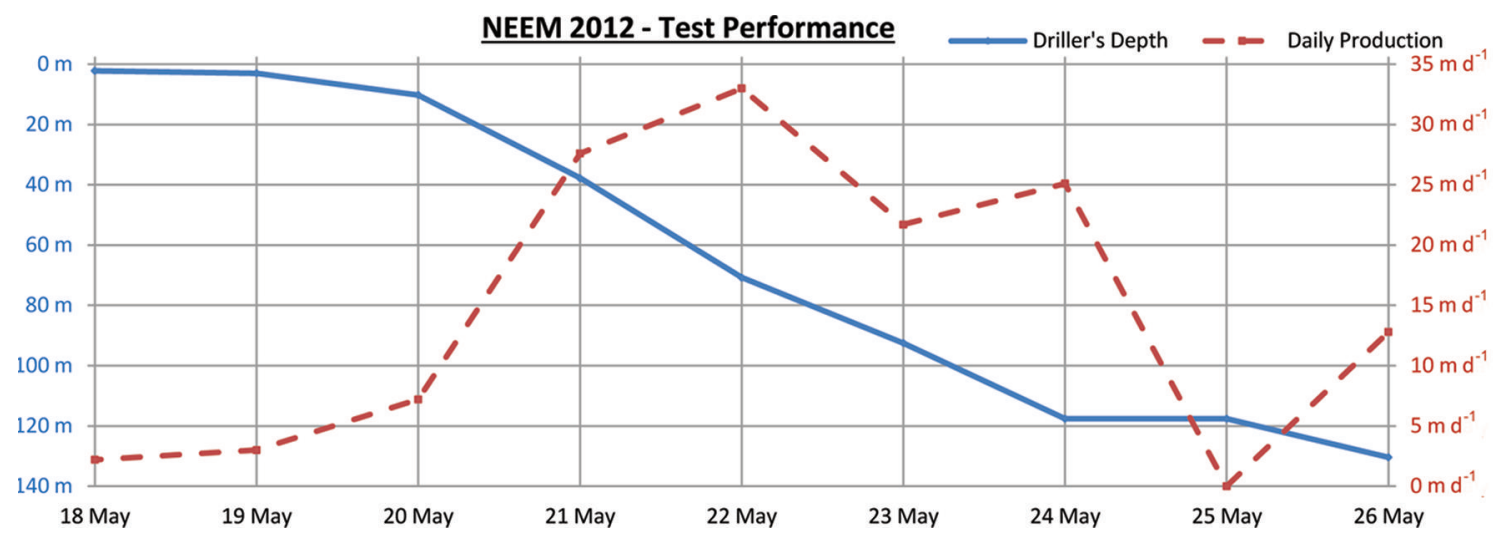

Fig. 17. In 8 days of tests $131 \mathrm{~m}$ of ice core is recovered, at production rates of $33 \mathrm{~m} \mathrm{~d}^{-1}$.

sturdy WeatherHaven tent shelter. Excavation, tent assembly, setting-up of the intermediate-depth drilling system, setting-up of ice-core logging equipment and a drill servicing table were accomplished within 4 days of arrival.

\section{ABN dry drilling operation}

In the following 5.5 days, $131 \mathrm{~m}$ of ice core was recovered with the drill set-up in 'dry' mode (Figs 24 and 25). During this period some very minor adjustments were made to the drill head for improving ice-core drilling in the increasing ice density, and some adjustments made to the winch control current feedback to stop the winch lowering or hoisting the drill when it should be stationary (Fig. 25). Generally, the first 3 days of the dry-mode operation was very smooth and quick. From 120 to $131 \mathrm{~m}$ the drilling in dry mode became difficult due to drilling penetration problems associated with chip transport issues within the core barrel and the outer core barrel. This chip transportation problem was caused by the chips being too small; their size could not be increased due to the limited number of possible drill-head cutter pitches available on site. At $131 \mathrm{~m}$ depth the dry drilling was terminated. The average ice-core

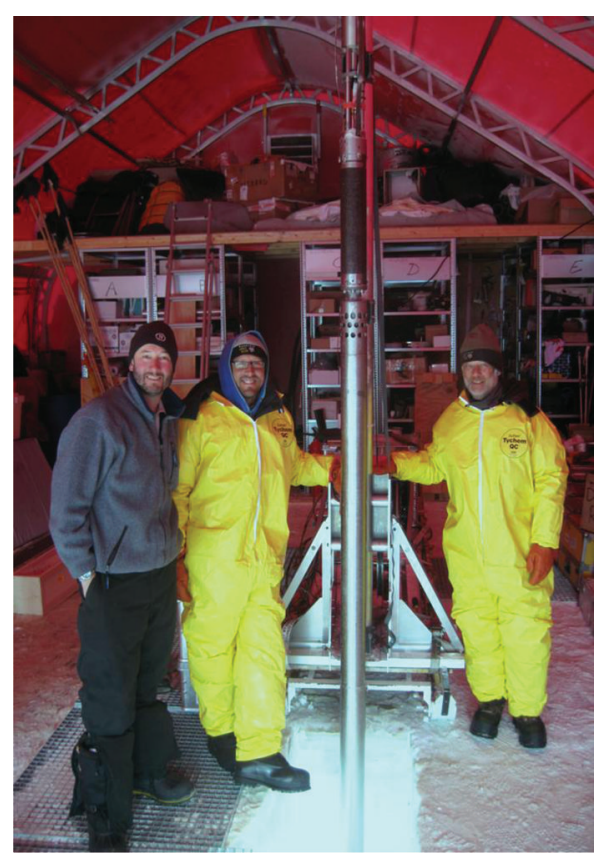

Fig. 18. System with field test team. production was $24 \mathrm{~m} \mathrm{~d}^{-1}$ on a single two-operator shift of $\sim 12$ hours $^{-1}$.

\section{ABN borehole reaming operation}

To remove the need for a reamer operation in 2011, a $130 \mathrm{~mm}$ diameter dry drill head was tested at NEEM using the shallow winch-and-tower system. Unfortunately, this produced excessive quantities of chips which caused the drill to be stuck on several occasions starting from $25 \mathrm{~m}$ depth. This resulted in two shallow winch motors burning out, in-the-field emergency repairs, and 9 drilling days lost. For $A B N$ we decided to return to our previous $126 \mathrm{~mm}$ diameter drill head (Fig. 26) configuration followed by reaming operation.

The dry drill head produces a nominal borehole of $126 \mathrm{~mm}$ diameter. The wet drill head produces a nominal borehole of $129.6 \mathrm{~mm}$ diameter. Therefore, after the dry drilling is completed and before wet drilling can commence, a reamer is used to increase the borehole diameter from $126 \mathrm{~mm}$ to $135 \mathrm{~mm}$. The Danish No. 1 reamer is mounted directly to the motor section, completely replacing the HT drill. The anti-torque, motor section and No. 1 reamer requires some repositioning on the tilting tower to achieve a balance. Initially, in the upper firn, the reamer can operate $\sim 7.5 \mathrm{~m}$ per run, which gradually reduces to $\sim 2 \mathrm{~m}$ per run by $\sim 50 \mathrm{~m}$ depth and below. Normally we might expect to use 1-2 days to ream the $131 \mathrm{~m}$ borehole; unfortunately, the reamer became stuck at $90 \mathrm{~m}$ and took a day to be freed. The following day the reaming began carefully again at $90 \mathrm{~m}$ and progressed without incident to $131 \mathrm{~m}$. A video camera was then lowered into the borehole to check for any problems.

\section{ABN liquid-mode drilling operation}

After the reaming operation was completed, a $200 \mathrm{~L}$ drum of ESTISOL ${ }^{\text {TM }} 140$ drill liquid was poured into the lower portion of the borehole using a $90 \mathrm{~m}$ long fire hose. This $200 \mathrm{~L}$ gives a liquid level of $\sim 14 \mathrm{~m}$ within the $135 \mathrm{~mm}$ diameter reamed borehole. The drill was set up in 'wet' drilling mode and then lowered to the base of the borehole. At the borehole base the $5 \mathrm{~m}$ long drill is completely submerged in the liquid, causing the liquid level to increase $\sim 1 \mathrm{~m}$ due to the displacement by the drill's closed volume. The buoyancy of the drill could be seen and measured by the load cell in the top sheave, equivalent to reducing the 'weight' by $\sim 100 \mathrm{~N}$, or $10 \mathrm{~kg}$. Drilling started and immediately the HT drill performed very well, producing successive excellent-quality ice cores (Fig. 27). The configuration of the HT drill was 


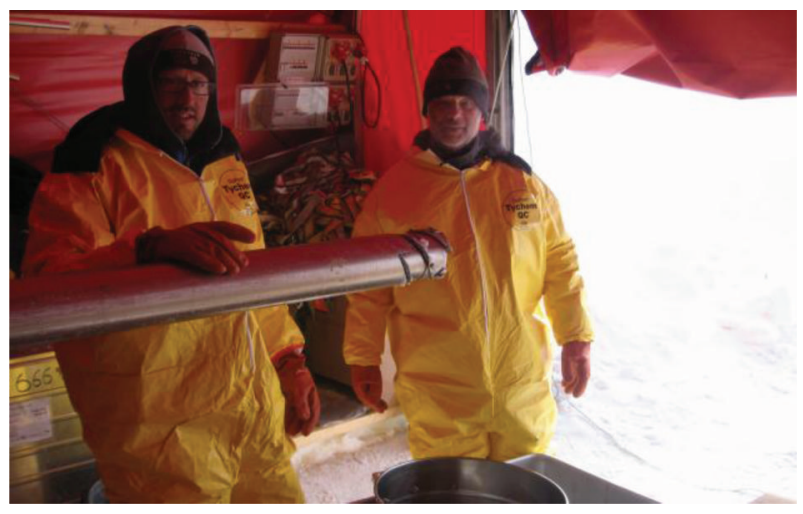

Fig. 19. Core barrel ready for extraction.

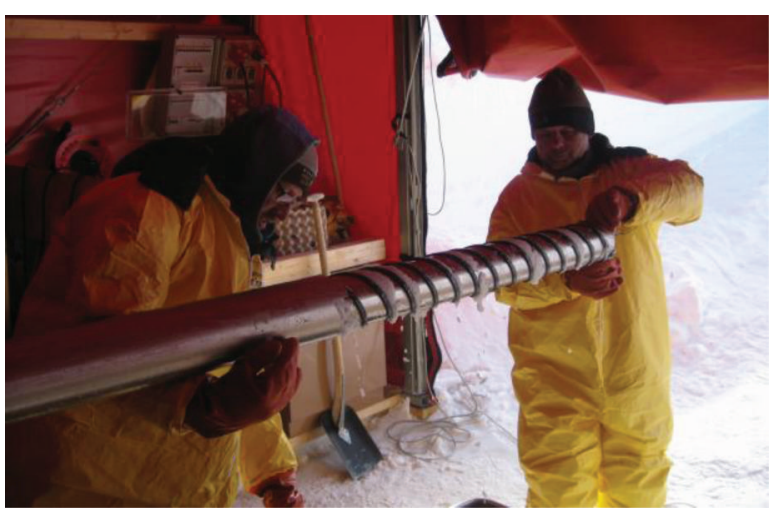

Fig. 20. Core barrel being extracted.

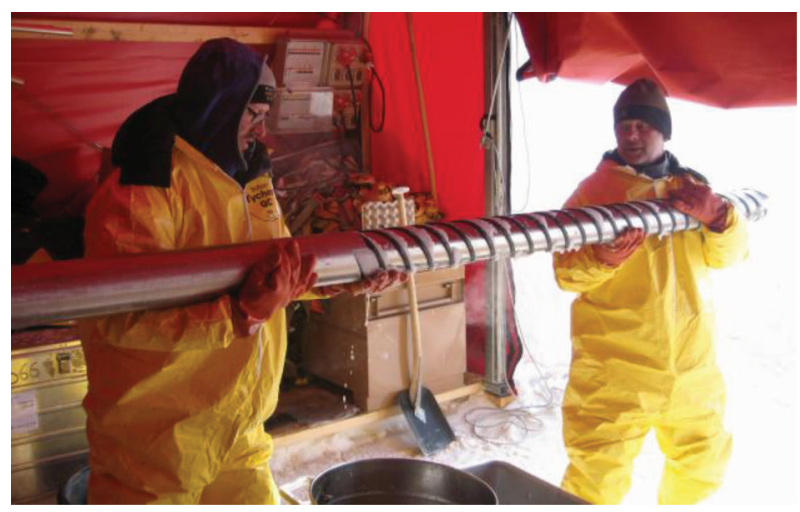

Fig. 21. Core barrel fully extracted.

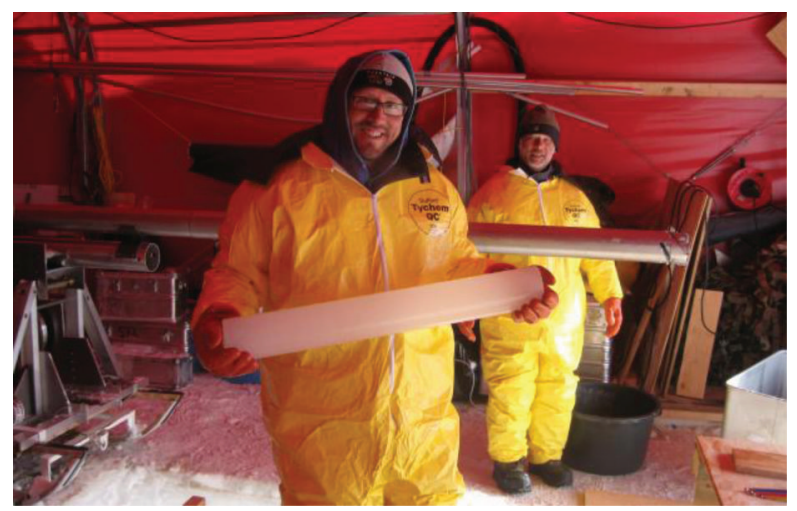

Fig. 22. Ice core from the core barrel.

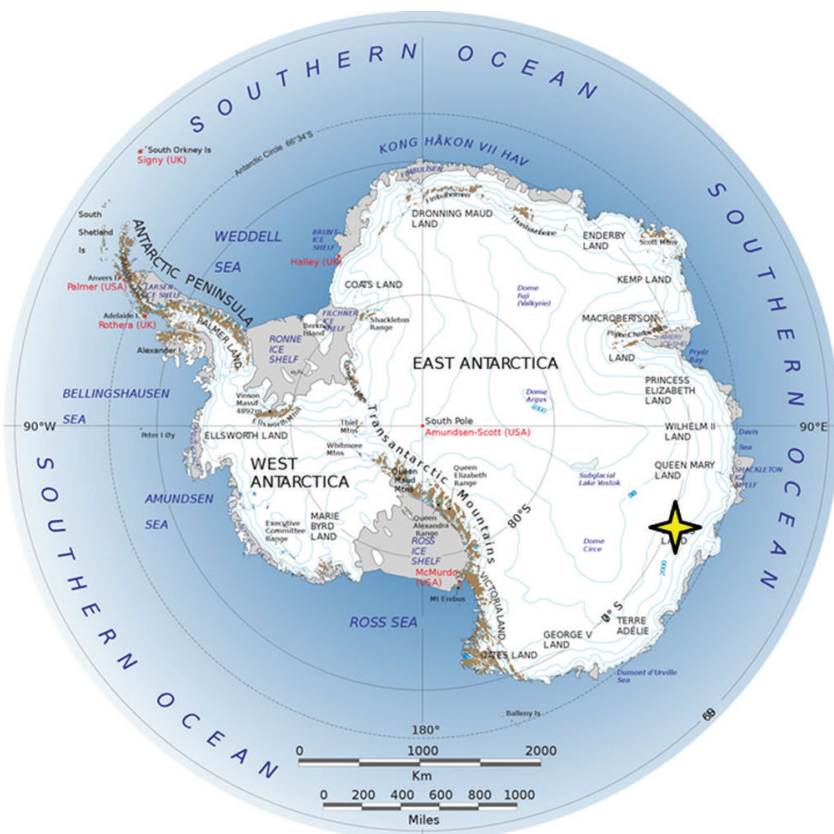

Fig. 23. $A B N$ site location (NASA).

essentially the same as used at previous drill sites using other drill liquids such as ESTISOL ${ }^{\mathrm{TM}} 240$ and EXXSOL ${ }^{\mathrm{TM}} \mathrm{D}-60$.

The wet-mode drilling operation progressed without significant incident for the following 10 days until the primary scientific goal, the recovery of a continuous $2 \mathrm{ka}$ ice-core record, had been reached and exceeded. The average daily production was $17 \mathrm{~m} \mathrm{~d}^{-1}$ with a single shift of two operators working for an average of 11 hours $^{-1}$. The average ice-core length was $1.32 \mathrm{~m}$ per run at $3.15 \mathrm{~m} \mathrm{~h}^{-1}$. During the wet drilling operation, there were four drill runs with significantly shorter ice cores. These were due to (1) two runs lost due to electrical plug problems, and (2) two cleaning runs after lost chips. There were also a number of runs on 9 January with reduced core length where the drill rotation speed was significantly lower than normal. This was

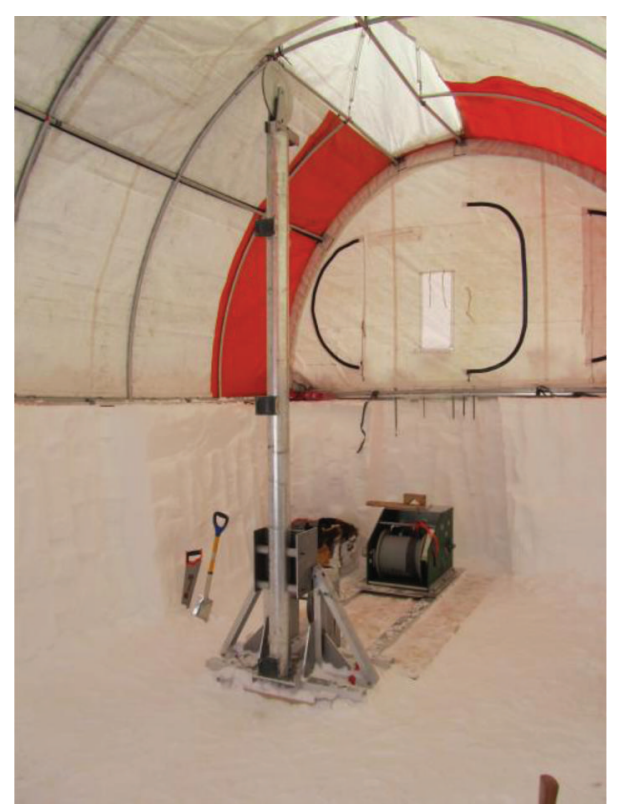

Fig. 24. Initial drill system set-up. 


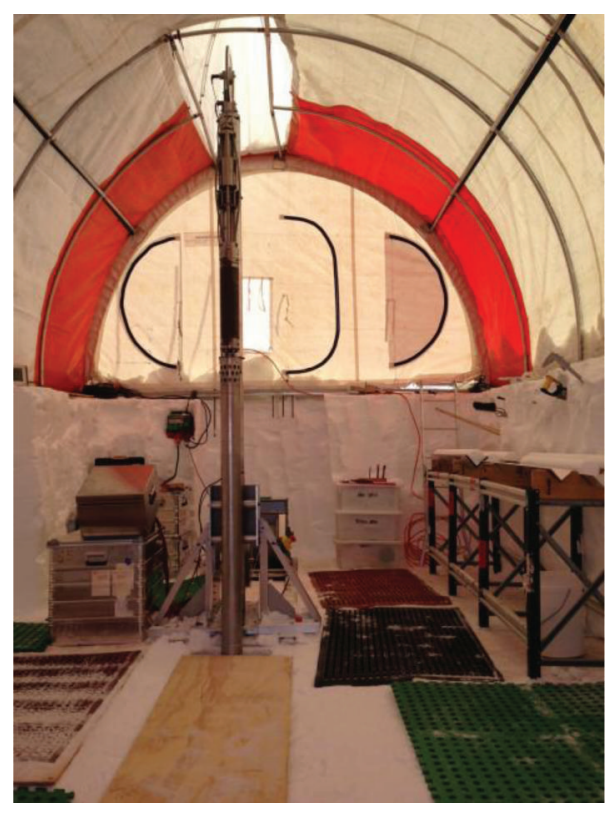

Fig. 25. Final drill system set-up.

due to hard ice building up in an external bearing in the motor section. Once the drilling operation had ceased, the complete packing-down of the intermediate-depth drilling system was completed within 24 hours.

\section{Drilling performance at Aurora Basin North}

During the wet-mode drilling operation the liquid column was regularly topped up, initially on a daily basis, and the liquid column height progressively increased from the initial $14-16 \mathrm{~m}$ to eventually $\sim 80 \mathrm{~m}$. This reduced stress-induced fractures in the ice core caused by the abrupt isostatic pressure release at the drill head, and thereby kept the icecore quality excellent throughout the operation (Sheldon and others, 2014).

\section{FUTURE SYSTEM DEVELOPMENT}

At present, the cable feeds onto the winch drum 'naturally', i.e. there is no special feed system other than the Lebus inner drum guide. Thus, as the drum rotates the cable falls into and follows the grooves from the lower layer of wound

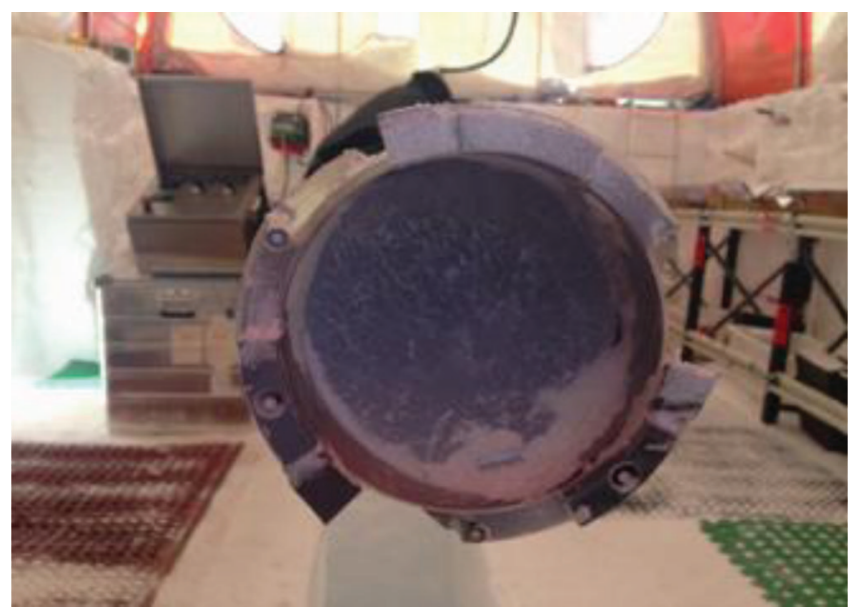

Fig. 26. Dry drill head containing ice core.

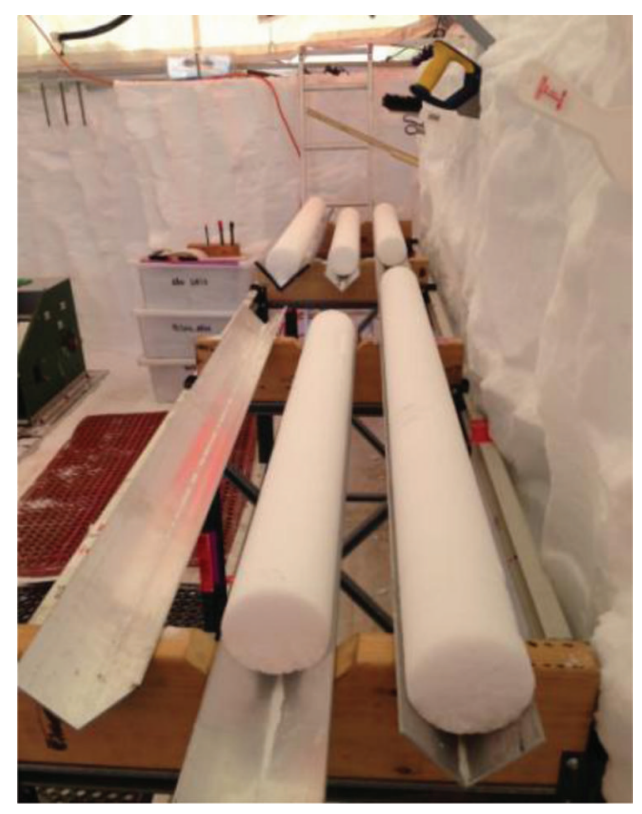

Fig. 27. First five ice cores from the firn.

cable. This has been found to work well at NEEM in 2012 and Aurora Basin North (ABN) in 2013/14 when the cable tension was $<2500 \mathrm{~N}$. But when the cable is being spooled onto the drum at the very extremities of the drum and when the cable tension is in excess of $2500 \mathrm{~N}$, the cable would sometimes slip towards the drum centre. This then required unwinding the cable back to the point where the cable followed the grooves and then rewinding at a tension less than $2500 \mathrm{~N}$. To reduce the time taken for this operation in the future, a winch cable level wind system is being developed to feed the cable onto the winch. This should be ready for use in our next drilling project, a possible $660 \mathrm{~m}$ ice core at Renland ice cap, East Greenland, in 2015.

During the liquid drilling operation at $A B N$ in 2014, we had several instances where we reached the programmed maximum torque limit set in the winch controller to $4 \mathrm{kN}$. This limit was not increased to the maximum tested limit of $5 \mathrm{kN}$ because these cores were recovered after two or three tries at breaking the core, and by this point the scientific goals were reached and then the drilling ceased. A concern for future drilling operations at depths greater than already tested is the ability of the winch to hoist the drill with 'hard core breaks', i.e. cores requiring $5-8 \mathrm{kN}$ (Mulvaney and others, 2014). In preparation for the possibility of these much higher required tensions, a new gearbox is being fitted to directly replace the present gearbox. This will take the gearbox ratio from $1: 11.92$ to $1: 22.3$, providing an extra $87 \%$ increase in available torque and increasing the theoretical cable tension using the motors' short time duty $\mathrm{S} 2,30 \mathrm{~min}$ at $1000 \mathrm{~m}$ depth, to $>10 \mathrm{kN}$. This will incur a consequential reduction in the hoisting speed range of $0.6-1.1 \mathrm{~m} \mathrm{~s}^{-1}$. This will be carefully tested before deployment and will require a change in the design of the present cable termination.

A new longer version of the HT drill is in the process of manufacture and should also be available in 2015. The primary objective of this new drill is to increase the drilled ice-core length by $30 \%$, from a maximum $1.60 \mathrm{~m}$ to $2.10 \mathrm{~m}$, thereby reducing the overall number of drilling runs and thus reducing the total time consumed by the drilling process. The 


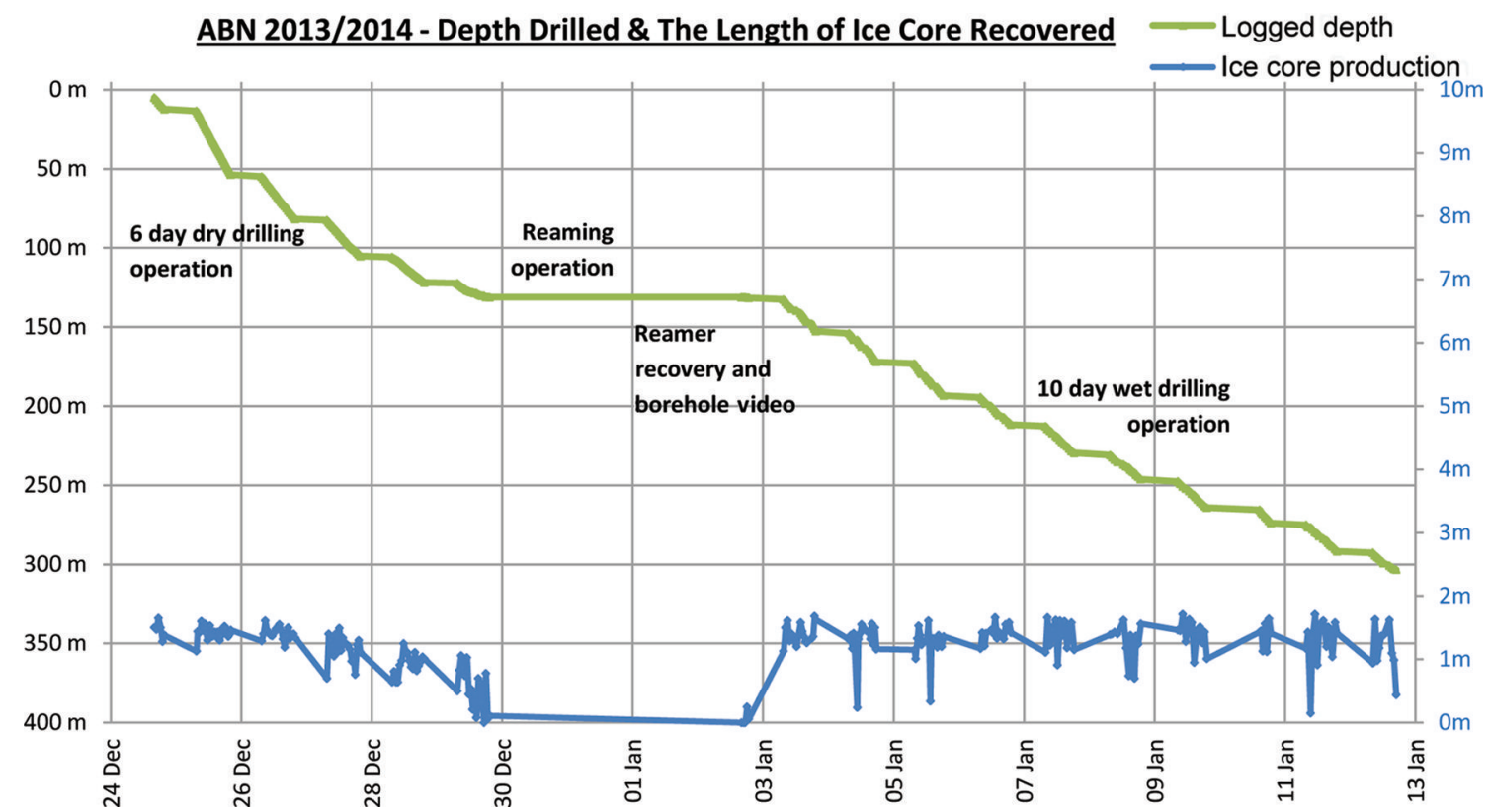

Fig. 28. Drilling commenced on the fifth day after arrival and finished 20 days later at $303 \mathrm{~m}$ depth, with an approximate ice-core age of 2000-2500 years. The equipment was then packed down within 24 hours and airlifted out of camp. Of the $303 \mathrm{~m}$ of ice core the first $131 \mathrm{~m}$ were recovered using the HT drill in a 'dry' mode set-up in 6 days, followed by a reaming process, with the final $172 \mathrm{~m}$ in 'wet'-mode set-up using the newly developed ESTISOL ${ }^{\mathrm{TM}} 140$ drill liquid. Drill performance during both stages and the retrieved ice-core quality were excellent at ice temperatures ranging from $-43.5^{\circ} \mathrm{C}$ to $-45.5^{\circ} \mathrm{C}$ and surface temperature ranging from $-25^{\circ} \mathrm{C}$ to $-4^{\circ} \mathrm{C}$.

new drill will incorporate a useful new feature used in our NEEM deep drill, a split outer core barrel and chip chamber barrel. This will reduce the maximum box dimensions to a more manageable length during transportation.

\section{SUMMARY}

This new intermediate-depth drilling system has the following attributes:

Produces high-quality $98 \mathrm{~mm}$ diameter ice core.

Accommodates the Danish HT drill, the future Danish HT 2.1 drill and the Danish shallow drill.

Operates from surface to depths in excess of $600 \mathrm{~m}$; a nominal $1000 \mathrm{~m}$ was an approximate aim.

Operates with fast run times: drill ascents and descents of $1 \mathrm{~m} \mathrm{~s}^{-1}$.

Low overall system weight.

Ability to set up quickly.

Operates within the limitations of a small-camp environment.

Easy for two persons to operate.

Drilling should be completed within a 3 month summer season.

Overall logistical and transportation costs are kept to a minimum.

Not excessively expensive to build or operate.

Reliable and easy to field-repair.

Ability to be set up directly on the snow surface or be mounted on a Nansen sled and then moved.
Ability to be transported

by Twin Otter,

by Basler Turbo 67 ,

by Hercules LC-130,

by normal international air freight.

Where possible, uses shared cross-platform components.

\section{CONCLUSIONS}

Ice cores have provided a great wealth of scientific data relating to past climate and environment (Jouzel, 2013). Recovery of this valuable material has required innovative and reliable solutions, carefully designed to cope with the harsh polar environment, yet very precise to recover continuous good-quality ice core. After several years of development the Centre for Ice and Climate, Copenhagen University, has a new intermediate-depth ice-core drilling system to complement the three previously developed icecore drilling systems. As such, this newly developed system increases the group's capabilities for ice-core recovery up to $1000 \mathrm{~m}$ at deep-field polar sites where project and logistical costs dictate a system that is both capable of recovering ice cores and also small, light, and easy to operate by a small number of drillers. The system design is versatile, with the ability to accommodate both the present shallow drill and the HT drill, but is also able to accommodate a new planned HT 2.1 drill.

The new system has performed effectively and efficiently both in field trials in 2012 at NEEM and in the ice-core drilling project in 2013/14 at ABN (Fig. 28), producing a continuous good-quality $98 \mathrm{~mm}$ diameter $2 \mathrm{ka}$ old ice core in a small-camp environment. The system can be set up within 2-4 days of arrival at a site and then be used quickly and easily by two or more operators from surface to intermediate drill depths. It can then be packed and sent out of camp within 24 hours. 
The new intermediate-depth drilling system includes the ability to be set up directly on the snow surface or be mounted and moved on a Nansen sled, can be transported by Twin Otter or Basler Turbo 67, has many new drill and operator safety features, allows fast drill ascent speeds, has high pulling force capabilities, has an integrated descent speed control and load-cell display, and the design and construction of many components are inter-operable and interchangeable with the other Danish drill and winch systems.

The entire system consists of

1. Denmark's successful HT drill, set up initially in dry mode, followed by reamer mode and then wet mode

2. A powerful low-weight intermediate-depth winch with the ability to hold up to $1400 \mathrm{~m}$ of cable

3. A newly built tilting tower system

4. A newly built fully integrated $2.6 \mathrm{~kW}$ winch-and-drill controller.

\section{ACKNOWLEDGEMENTS}

We thank the various funding agencies for supporting this project including the development costs and cost of field tests. Special thanks goes to the Niels Bohr Institute for mechanical manufacturing and engineering support, and to the NEEM Project for field trial support. We also thank all the logistical people for organizing the field camps and for bringing us there along with our equipment, and the numerous drillers for their vital contribution to improving the drills and drilling techniques. We are greatly indebted to the various funding agencies for supporting the NEEM icecore drilling projects. NEEM is directed and organized by the Centre for Ice and Climate at the Niels Bohr Institute, and the US National Science Foundation (NSF) Office of Polar Programs. It is supported by funding agencies and institutions in Belgium (FNRS-CFB and FWO), Canada (NRCan/GSC), China (CAS), Denmark (FIST), France (IPEV, CNRS/INSU, CEA and ANR), Germany (AWI), Iceland (Rannls), Japan (NIPR), Korea (KOPRI), The Netherlands (NWO/ALW), Sweden (VR), Switzerland (SNF), United Kingdom (NERC) and the USA (US NSF, Office of Polar Programs). We thank the Australian Antarctic Division and all contributors to the Aurora Basin North project for their support.

\section{REFERENCES}

Johnsen SJ and 16 others (2007) The Hans Tausen drill: design, performance, further developments and some lessons learned. Ann. Glaciol., 47, 89-98 (doi: 10.3189/172756407786857686) Jouzel J (2013) A brief history of ice core science over the last $50 \mathrm{yr}$. Climate Past, 9(6), 2525-2547 (doi: 10.5194/cp-9-2525-2013)

Mulvaney R, Triest J and Alemany O (2014) The James Ross Island and the Fletcher Promontory ice-core drilling projects. Ann. Glaciol., 55(68) (doi: 10.3189/2014AoG68A044) (see paper in this issue)

Sheldon SG, Popp TJ, Hansen SB and Steffensen JP (2014) Promising new borehole liquids for ice-core drilling on the East Antarctic high plateau. Ann. Glaciol., 55(68) (doi: 10.3189/ 2014AoG68A043) (see paper in this issue) 